\title{
Economically irrational pricing of nineteenth- century British government bonds
}

\author{
ANDREW ODLYZKO \\ University of Minnesota
}

\begin{abstract}
British government bonds formed the deepest, most liquid and most transparent financial market of the nineteenth century. This article shows that those bonds had long periods, extending over decades, of anomalous behavior, in which Consols, the largest and best known of these instruments, were noticeably overpriced relative to equivalent securities which offered the same interest rate and the same guarantee of payment. This finding and similar ones for other comparable pairs of British gilts appear to provide the most extreme counterexamples documented so far to the Efficient Markets Hypothesis and to the Law of One Price, and point the way to further investigations on the origins and nature of the modern economy.
\end{abstract}

Keywords: pricing anomalies, violations of Efficient Markets Hypothesis, Law of One Price counterexamples

JEL classification: BI 5 , E43, Gio, Gi I, GI2, Gi4 , G24, H63, H8 I, N23

Nineteenth-century Britain led the world in the development of modern economic and financial institutions as well as of economic theory. This article shows that these developments were accompanied by a striking example of large-scale economic irrationality that adds a new dimension to the modern literature on market efficiency and pricing anomalies. (See Section IV for a comparison with other results in that area.) The most notable instance involved relative mispricing of two extremely large British government bonds, which carried exactly the same interest rate and were backed by the full faith and credit of the government. They differed essentially only in name, volume and dates interest was paid. The price difference, adjusted for accrued interest,

A. Odlyzko, School of Mathematics, University of Minnesota, Minneapolis, MN 55455, USA; email: odlyzko@umn.edu; www.dtc.umn.edu/ odlyzko. Comments from the anonymous referees and the editor are gratefully acknowledged. Thanks are also due to Ron Alquist, Rob Brown, Jan Klovland, Larry Neal, Richard Sylla and the Nineteenth Century Subfield group at the University of Minnesota (especially Michael Hancher) for comments and information, to the Times Newspapers Ltd Archive for information from their files, and to Yuxi Chen, Yuanshun Yao, Yilin Zhai, Yiqun Zhang, Jialu Zhong and Ying Zhu for assistance in transcribing and checking transcriptions of gilt prices. The many other individuals and institutions that assisted in the larger research project of which this is a part are thanked at www.dtc.umn.edu/ odlyzko/doc/mania-ack.html. 
exceeded 2 percent for short periods, and averaged over I percent for several years, and over 0.5 percent for decades, as is shown in Figure I. (The notation is explained lightly in the figure caption, and in full detail in Section II.) The potential arbitrage profits from eliminating the discrepancy reached I percent of UK GDP at the peak in the mid I860s. The sizes of the British economy, national debt and the main government securities of that period are shown in Table I, based on standard sources. Figures for GDP come from Mitchell (I988), and are at current market prices. The data for total national debt, and volumes of major gilts are taken from Parliamentary Papers such as I850 (I69) XXXIII. I, and represent the nominal value, not the market value, of each. National debt given is the sum of the funded and unfunded components. The terminology used here is rather loose, in that figures that are cited as describing the British economy and debt actually cover all of the UK, which included all of Ireland in the nineteenth century.

The existence of this mispricing is interesting in itself, as it raises doubts about the various series of long-term interest rates for nineteenth-century Britain (see Homer and Sylla I996; Klovland I994). Those were all derived from market prices of Consols. However, as Figure I shows, for much of that century slightly different rates held for much of the other half of the national debt.

While only one contemporary economist, Robert Giffen, appears to have written about this pricing anomaly (which by itself raises interesting questions), it was widely known among those involved in finance, even if not among the general public. Some Chancellors of the Exchequer (the equivalent of a finance minister in many countries, or the Secretary of the Treasury in the US) spoke about it in Parliament, and it was cited in a popular textbook on arithmetic. Several newspapers waged extended campaigns, attempting to persuade their readers to take advantage of this mispricing. Such efforts had little noticeable effect. This mispricing was eliminated only in I 888, when almost all gilts (the modern term for British government bonds) were converted to a single new class. The memory of this pricing anomaly faded away quickly afterwards. There does not seem to be any mention of it in the modern literature.

The City (the commercial and financial heart of London), the London Stock Exchange and British financial markets of the nineteenth century in general have been investigated extensively, since London was the world's dominant financial center during that century. Some of the basic references are Atack and Neal (2009); Davis and Neal (I998); Kynaston (1994); Michie (1999); Morgan and Thomas (I96I); Neal (I993); Neal and Davis (2006). In particular, the development of the key institutions and laws is well documented. The last few decades have also produced an extensive literature on some other aspects of those markets, such as that in Green et al. (2OI I).

This article concerns another issue, one that has been not just neglected, but appears totally unknown to modern scholarly literature, namely the pricing anomalies of British gilts in the nineteenth century. Trading in those bonds was the reason the London Stock Exchange was created. (The word 'Stock' then referred primarily to government perpetual annuities, Consols the most prominent of them.) They 


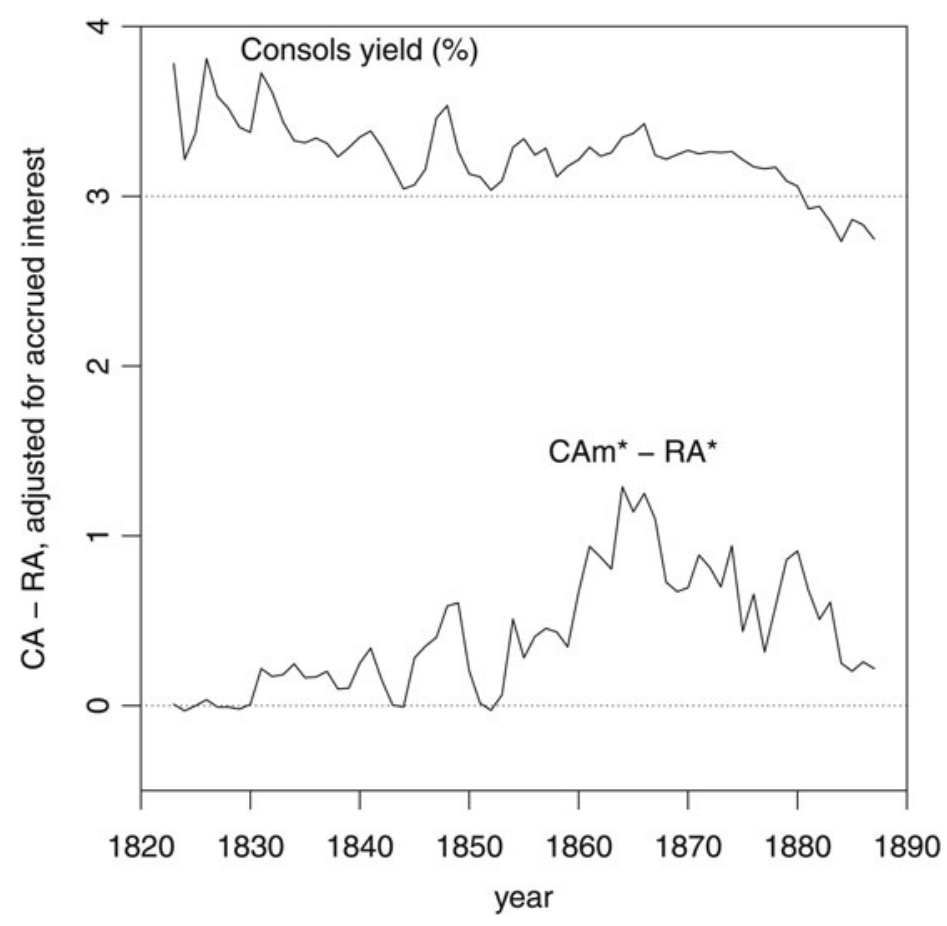

Figure I. Average annual overpricing of Consols (CA) relative to Reduced Annuities (RA), 1823-87 Note: Stars denote market prices after subtraction of accrued interest, in pounds sterling for a unit of nominal value $\mathcal{E}_{\mathrm{I}} \mathrm{IoO}$. In an efficient market, $\mathrm{CAm}{ }^{\star}-\mathrm{RA} \star$ should have been zero. Also shown is the average annual market yield on Consols. Prices from the Course of the Exchange and the Economist.

provided almost all the trading volume on that exchange for the first two decades of the nineteenth century, with shares of companies such as the Bank of England, and then increasingly also canals, insurance companies, etc., being almost negligible. Around I 820 , foreign government bond trading became prominent, and then, in the I830s and I840s, shares of joint stock companies, railways foremost among them, grew in importance. A contemporary compilation claimed that in the I 8 I6-20 period, UK national debt amounted to about 67 percent of all tradeable financial securities in the world, with the Dutch debt in second place at II percent. ${ }^{1}$ Even in the early I 860 s, as other nations grew their debts, the UK accounted for about 40 percent of world total of national debts (Levi I 862), at a time when such securities were still far larger in volume than equity investments.

1 Table on p. 29I of the 5 th edition, published in I 855 , of Nash (I 874). There is a mistake in addition in

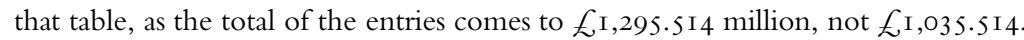


Table I. British economy and national debt, 1840-80

\begin{tabular}{lrrrrc}
\hline \hline Year & GDP & Debt & CA & RA & NR \\
\hline I840 & 566 & 798 & 362.2 & I26.I & - \\
I850 & 593 & 798 & 374.2 & I2I.3 & 247.8 \\
I860 & 828 & 802 & 400.6 & II 5.0 & 246.2 \\
I870 & I,I 53 & 748 & 393.6 & IO2.7 & $220 . \mathrm{I}$ \\
I880 & I,379 & 738 & 390.9 & 92.3 & 204.2 \\
\hline \hline
\end{tabular}

Note: All figures in millions of pounds sterling. CA, .., $\mathrm{R}_{35}$ designate certain bonds, and entries in those columns are nominal values of outstanding debt in the corresponding security. Data from Parliamentary Papers.

Consols, denoted CA in Table I and in the rest of this article, are a natural subject for study. In the words of a modern scholar, '[a]s a measure of the long-term rate of interest [CA] perhaps comes as close as we can get to that theoretical abstraction, which requires a loan of infinite duration without any risk of default' (Mitchell I988, p. 649). Not only was their volume large, but they were book-entry entities, were long-lived (dating back to early I750s, and replaced by a new but similar type of bond, with a lower interest rate, also called Consols, in I 888-9), were almost infinitely divisible (some accounts had just one penny, the old British penny, I/240th of a pound sterling, in them), and were traded all the time on the London Stock Exchange with low (for that time) transaction costs.

Modern authors who have looked at long-term interest rates in Britain have studied CA to the almost complete exclusion of other gilts (see Brown et al. 2006; Capie and Webber I985; Gayer et al. I953; Heim and Mirowski I987; Homer and Sylla I996; Klovland I994; Mitchell I988; Siegel 1992). All published studies have found that the nineteenth-century gilt markets passed those standard efficiency tests that were applied (Brown and Easton I989; Brown et al. 2006; Mitchell et al. 2002). However, those studies used data just for CA.

While CA did constitute about half of the British national debt, there was another half. Even if we exclude short-term debt, for most of the nineteenth century there were between half a dozen and a dozen government securities on the market. They offer a rich subject for study. This article concentrates on what are called here the 'major gilts' of the I $845-7$ period, namely the ones listed in Table I. They are explained in Section II, and had the property that their capital was large, they were widely held and we have prices for them for almost every day that the London Stock Exchange was open. It turns out that these major gilts displayed some striking and time-varying but persistent pricing anomalies, as shown in Figure I.

This article is based on two new collections of data. One is an extensive dataset of gilt prices in the I 823-88 period, primarily of the major gilt, but also of some minor ones. It is publicly available on the author's home page, www.dtc.umn.edu/ odlyzko/19finance/. The other collection is of notes and discussions about gilt 
mispricing in the contemporary literature, primarily the press, but also books, pamphlets and official documents. They are cited frequently with full references in this article, as well as in the supplementary manuscript (Odlyzko 20I4). That manuscript considers in more detail the behavior of CA overpricing during various interesting periods, the coverage of that phenomenon in the press, and the gilt investments of various groups, such as the universities of Cambridge and Oxford. It also has more details, in most cases not available in modern literature, about data sources, gilt ownerships and the functioning of nineteenth-century gilt markets. Some statistics of operations of the London Stock Exchange that were obtained recently are available in Odlyzko (2016).

Possible reasons for the observed mispricing are discussed in Section IX. It is argued there that the standard candidates (liquidity, government actions, seasonality, etc.) do not suffice to explain this phenomenon. The tentative conclusion is that most of the time it resulted from a combination of widespread ignorance (so inefficient information markets), of mass psychology that led British investors to think of CA as being more prestigious than RA, and be willing to pay a bit more for it, and of a cultural disdain for overt attention to money, leading to reluctance to deal with minor financial matters. This was also the conclusion of Giffen and some other contemporary observers. But even this is not entirely satisfactory, as there were periods in the late eighteenth century when RA was overpriced relative to CA.

Current literature abounds in examples of inefficiencies in modern bond markets. See, for example, the papers Fleckenstein et al. (20I4); Kuipers (2008); Lagos and Rocheteau (2008); Musto et al. (2013) and the references there. Explanations have been offered for some of those inefficiencies as products of short-selling constraints, liquidity, deliverability, etc. To the extent those explanations are correct, market participants are not irrational in their individual actions, but special circumstances lead to pricing inefficiencies. Many of these explanations can be shown to be inadequate to justify the observed mispricing of nineteenth-century British gilts. But not all can be excluded as irrelevant, since the data we have are too limited. So the argument of this article is based just on the inactions of one particular class of investors. Those were the people in charge of perpetual trusts. Liquidity, marginability, etc. were irrelevant to them, as they were constrained to investing in gilts, and could only pay out the income from their investments. Why didn't they exchange their overpriced CA for underpriced NR and RA? They would have gained a little extra income for their beneficiaries, and their counterparties would have gained the liquidity and other properties of CA that might be of use to them. Some contemporary explanations for the mispricing were based on the assumption that such a partitioning had taken place, and that CA was owned by the speculators, while the 'cheaper and quieter' NR and RA, in the words of a leader in The Times, were the province of 'Savings Banks, trustees, small capitalists, and other permanent holders'. ${ }^{2}$ However, evidence shows such segregation had not taken place to any great extent, as we find very large

2 The Times, is February I870, p. 7. 
trust investments in CA. So the argument of this article is not that all investors were economically irrational, just that one particular but large class of investors was irrational in its investments, as it had no way to benefit from any of the possible advantages of CA.

Section II describes the major gilts that are the main subject of this study. Section III discusses CA overpricing relative to RA, which is pictured in Figure I, but over shorter periods, to demonstrate some of the features of this phenomenon in more detail. Section IV compares the gilt mispricing discovered in this research to pricing anomalies that have been published earlier. Then come sections dealing with arbitrage and its limitations, government's role in gilt mispricing, and the influence of liquidity. Section VII summarizes the coverage of gilt mispricing in contemporary literature. Section VIII demonstrates the heterogeneity of market actions of several groups. Next comes a discussion of possible reasons for the observed mispricing, and finally the conclusions.

This section reviews basic facts about gilts that are well known to scholars who have studied that period. References and new material (such as studies on liquidity, gilt ownership, etc.) are available in Odlyzko (2014, 2016).

The main subjects of this study are the three major gilts that formed the bulk of the British national debt in the I $845-88$ period:

- CA $=$ Consols, the Consolidated 3 percent Annuities of I75 I, paying 3 percent annually, in early January and early July

$-\mathrm{RA}=$ Reduced 3 percent Annuities, also dating to the I750s, paying 3 percent annually, in early April and early October

$-\mathrm{NR}=$ gilts created from earlier 3.5 percent annuities in the I 844 debt conversion, paying 3.25 percent from late I 844 to late I 854 , and then 3 percent, with a guarantee of no redemption until late I 874 , with interest payable on the same days as RA

After I 854 these three securities all paid 3 percent per year (actually about 3.02 percent, since they paid I.5 percent twice a year, but we'll follow the convention of the time and disregard this pedantic point) and were collectively often referred to as 'the Three per Cents'. They were called 'perpetual', in that investors could not cash them in, but the government could call them by paying face value. Such redemptions happened a number of times in the nineteenth century with various gilts. In a recent book some of them are listed as examples of 'domestic default or restructuring' (Reinhart and Rogoff 2009, p. I I2). This is misleading, since the British government was punctilious in observing all its legal obligations. These conversions took place in times of prosperity, following all the legal rules, when interest rates were low. CA, RA and NR were all liquidated in the I 888-9 Goschen conversion, during one of those periods, and replaced by a new gilt that initially paid 2.75 percent, declining to 2.5 percent in I903.

Prices for gilts were universally quoted in units of nominal (par) value of $\mathcal{E}_{\mathrm{I}} \mathrm{\text {oo }}$.oo, even though transactions could and were carried out in units as small as I/240th of 
EI.Oo. Transaction prices and quotes for the major gilts were almost always reported in increments of fo.r25 (for a unit of par value $\mathcal{L}_{\mathrm{IOO}}$ ). This was also the standard brokerage commission, and also the jobber (market maker, specialist) standard margin (difference between buy and sell quotes, then called the 'turn'). Large customers could normally get better deals, while in times of stress, the jobber margin would

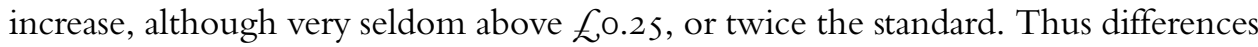
in price of fo. 25 during that period were in general not significant, and could often be due just to the drift of prices and the timing of transactions that were reported. ${ }^{3}$ Figure 2, based on daily data for I 864, gives a sense for the effect of this granularity in the data. (The tables have far more information.)

When retail investors sold a security and immediately purchased another one, they usually paid only one commission (Tuck I845, p. I4). Hence such investors could engage in profitable arbitrage when mispricing exceeded fo.25, but not below. Large investors and insiders could profit from smaller differences.

While almost all share transactions were subject to a stamp tax, gilts trading was exempt. Also, income tax (which was brought back in the early I840s) was at low levels and did not apply to capital gains. Hence taxes are disregarded here in considering potential arbitrage.

Most gilts traded for immediate cash settlement. CA was exceptional among gilts in also having throughout this period trading 'for account', to be settled later, a form of futures trading. Prices were reported separately for cash trading (denoted in this article as CAm) and for account (denoted CAa). While tables report both, all studies have been carried out with CAm, in order to avoid the technical adjustments that would need to be made to obtain comparable figures from CAa.

Until I 86I, each gilt had trading in it suspended for about a month before the interest payment date. This meant that we have prices simultaneously for both RA and CAm for only eight months each year, and all the statistics that are reported reflect this. ${ }^{4}$

Before I86I, we can find some published advice for banks to keep half of their reserve in CA and half in RA. After I86I, that became irrelevant, and so there may have been a migration of large large active investors to CA. ${ }^{5}$

Gilts traded in London with accrued interest, with prices dropping when interest (then usually called dividends) was paid. The ${ }^{\star}$ symbol is used to denote the price after subtraction of accrued interest. Rational pricing based on fundamental economic values would call for $\mathrm{CAm}^{\star}-\mathrm{RA}{ }^{\star}$ to be close to zero.

3 Averaged over longer periods, though, they could indicate a trend.

4 Use of CAa to supplement CAm when CA was 'shut' would increase the coverage period to Io months, but was again not implemented to keep the arguments simple.

5 We do find an increase in CA overpricing in $\mathrm{I} 86 \mathrm{I}$, but it is not certain it was due to this factor, as the increase in overpricing was already noticeable in I860, and the all-time high occurred in I864, quite a long time after the change. We can show quantitatively, though, that CAa gradually became much less actively traded after the abolition of 'shuttings'. 


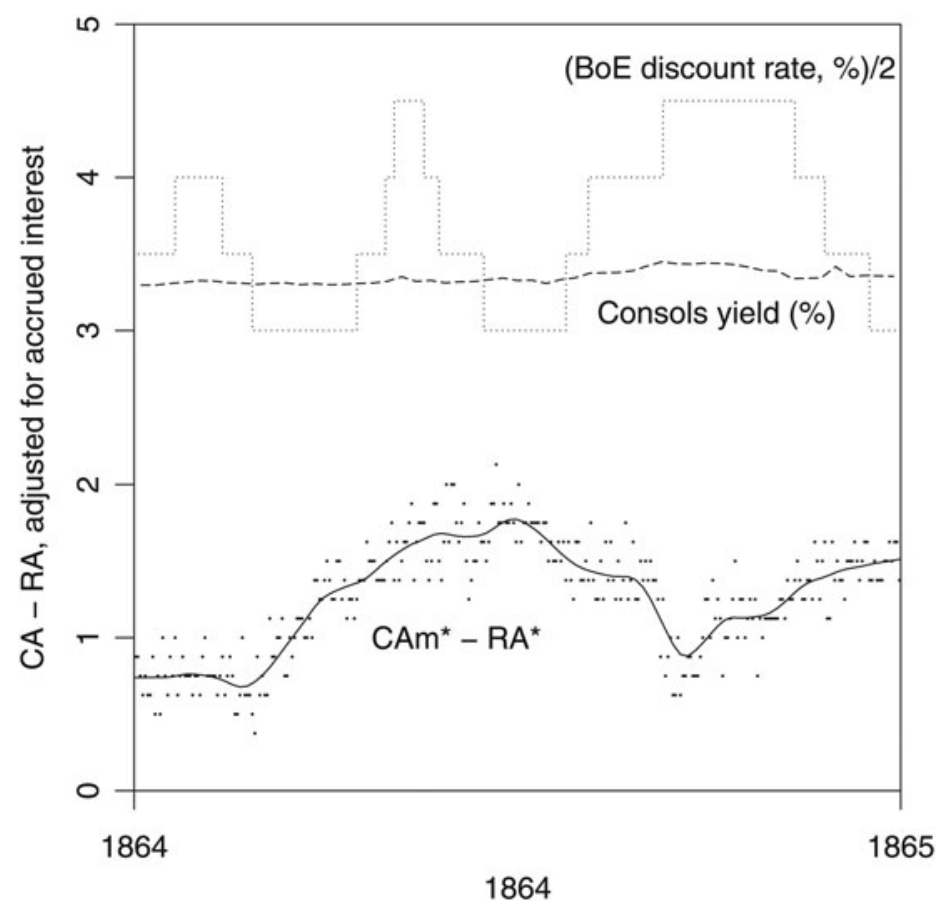

Figure 2. Overpricing of Consols relative to Reduced Annuities in 1864

Note: Based on daily closing prices from Course of the Exchange adjusted for accrued interest, Bank of England discount rate divided by two to fit the graph, and market yield on Consols. The solid line is a smoothed version of the scatter plot.

The values of CAm ${ }^{\star}-\mathrm{RA} A^{\star}$ that are actually reported in the tables come from either subtracting or adding fo.75 to CAm - RA, depending on which security had an interest payment next. This would be exact if the interest payment dates were precisely a quarter of a year apart, interest accrued linearly, and interest rates were the same for all maturities (constant term structure). None of these assumptions is correct, but the difference between the approximation and the correct value was generally well under fo.05, so was ignored. That this was an approximation, but one 'good enough' for practical purposes, was known two centuries ago (see Wade I 806$)$.

The data for this study came primarily from two sources. The Course of the Exchange, abbreviated as CoE, provided most of the data for the period I 823-60, mainly in the form of closing prices on Fridays. The Economist was used to obtain the Friday closing quotes for I 86I-87 (for some years for all Fridays, for some for samples of I6, usually 4 from each of February, May, August and November), and the bid quotes were used in the statistical studies and graphing. However, for some periods additional, more detailed, datasets were collected (such as the daily closing prices used to prepare 
Figure 2). At this point it should be noted that these sources are standard ones that have been used in previous studies. CoE and Economist data lead to essentially identical estimates of gilt mispricing for the periods where they overlap.

Gilt prices were reported in practically all British papers in the nineteenth century, usually in either the CoE or the Economist form. Thus the data demonstrating pricing anomalies were visible to newspaper readers on a constant basis, although to realize the figures represented mispricing required the ability to calculate accrued interest.

Figure I summarizes the evolution of CA overpricing during the period I 823 to I 887 . The underlying data, as well as the annual averages that are displayed in this figure, are all in the auxiliary tables. Here we consider some observations on the data.

It appears that not infrequently, modest increases in CA overpricing came, with some delay, after big economic shocks. This applies to the first appearance of extended CA overpricing that was observed in this (post-I 822) study, which occurred in I83 I. In the fall of 1830 there was a dramatic increase in interest rates, followed by more turbulence in early I83 I. But the largest overpricing of CA occurred in April and May of I83I, when the markets were rebounding. Similar observations apply to the crises of I 847 and I 866 .

Not all increases in CA overpricing can be associated with obvious economic or financial shocks. In particular, the record high levels of CAm* $-\mathrm{RA}$ * that were found in this study occurred in I864, and are depicted in Figure 2. The scatter plot there presents the values of CAm ${ }^{\star}-\mathrm{RA}^{\star}$ for each of the 305 trading days that year when prices of both CAm and RA were available, and the solid line is a smoothed version of the scatter plot. One reason for presenting this graph is to provide a sense of the quality of the data. The only unusual feature of the economic scene, although one that attracted considerable attention in the press, was that short-term interest rates were high, and were fluctuating with great frequency. However, there were no serious economic or political threats.

If CA was more highly valued than RA (and NR, after I 854), what happened when the supply of CA increased suddenly? One large increase took place in early I 847, primarily to provide funds for the relief of the Irish Famine. It increased the supply of CA by about 2 percent. There was an even larger increase (about 4 percent) in early 1855 , to provide funds for the Crimean War, and two smaller increases in early I 856 , also for this conflict. The loans for I 847 and I 855 may have contributed to the observed slight reductions in CA overpricing. The ones of I 856 appear to have had little if any effect, in that the overpricing seems to have increased afterwards.

The tables have detailed pricing data for those and a number of additional periods. The hope is that with more data and deeper investigations, we will obtain insights into gilt mispricing. For example, daily data, including both closing prices and closing 
quotes, can provide us with insights into the efficiency of the market in dealing with unexpected developments, insider leaks and the like.

The statistics that are available now do not provide much insight into what may have driven the observed overpricing, although they do tend to rule out some possible mechanisms. As the tables show, there was at least one two-month period in 1787 when RA was rather consistently overpriced relative to CA. So features such as availability of trading for account did not automatically make CA more valuable, something that can also be seen in the extended periods when CA and RA were priced rationally relative to each other.

The I 787 reversal of the usual pattern was found through sparse sampling, and a thorough comparison of CA and RA pricing for the full period they coexisted is yet to be done. During the main period that this study covers, I 823-88, CA was never significantly underpriced. An attempt was made to relate its degree of overpricing to some other available financial measures. Ideally, one would like to compare CA overpricing to continuation rates (fees to carry over a position in CA from one account to another) as well as to overnight rates with gilts as collateral. For the latter, we have evidence that at least in the early I 840 , they varied from hour to hour, and also from one security to another (Parliament I842). Unfortunately, for most of the nineteenth century newspapers published only occasional reports, which usually mentioned just a generic rate for lending on gilts. It is only in the I880s that the growth in sophistication of the financial press led to more detailed reports. For example, the earliest series of CA continuation rates that has been found is that in The Times, and it only starts in May I883. However, during the period from May I883 to the end of I887, CA continuation rates matched closely the Bank rate, the Bank of England rate of discount, with correlation coefficient 0.78 . So from I 850 to I 888 , the Bank rate was used as the generic shortterm rate. It is not perfect, in that during this period the Bank of England was trying to find its proper role in the spectrum between being an ordinary bank, competing with others, and being a central bank. Still, it seems about the best measure of short-term rates during that period that is available.

Before the I 844 Bank Act, the Bank rate was not very representative of market conditions. Of the few available alternative short-term rates, the best one, and the one that was used between I 830 and I 850 , was that for bills of exchange from the Overend, Gurney bill house (Parliament I 857, pp. 463-4). Long-term rates throughout this period were those of CA yield, after making the necessary adjustments for accrued interest (Klovland I994).

The period I $856-80$ is perhaps the best test for relations between CA overpricing and general financial conditions, since long-term rates were high enough to preclude serious concerns about redemption of CA and RA. For those 25 years, the correlation of $\mathrm{CAm}^{\star}$ - RA with short-term rates was 0.29 , and with long-term rates it was 0.53 . (The correlation coefficient between long and short rates was 0.68 in that period.) So CA overpricing was only moderately connected with interest rates, and of those, much more with long-term than with short-term ones. 
In the I830-52 period, the correlation coefficients of CAm $\star-R A$ with long-term and short-term rates were 0.37 and $0.4 \mathrm{I}$, respectively. Hence again we lack evidence of a direct link from general money market conditions to CA overpricing.

NR was created in I 844 to replace four 3.5 percent annuities. Two of them, which will be designated R35 (for Reduced 3.5 percent Annuity) and N35 (for New 3.5 percent Annuity), were large, with $\mathrm{N}_{35}$ larger than RA. Both traded only for cash settlement, with the larger $\mathrm{N}_{35}$ paying interest on the same days as CA, and R35 on same days as RA. Thus the pair $\mathrm{N}_{35}, \mathrm{R}_{35}$ was in many respects analogous to the pair CA, RA. Intriguingly, we find frequent relative mispricing of $\mathrm{N}_{3} 5$ and $\mathrm{R}_{35}$, with $\mathrm{N}_{35}$ usually overpriced, in analogy to the CA vs RA mispricing. The correlation coefficients between $C A m \star-R A^{\star}$ and $\mathrm{N}_{35}{ }^{\star}-\mathrm{R} 35^{\star}$ are 0.22 for the period I $83 \mathrm{I}-9$, and 0.50 for $1840-4$. Thus whatever drove those mispricing, it was not exactly the same factor for the two pairs of CA and RA and of N35 and R35. In particular, it apparently was not some simple function of money market conditions.

\section{IV}

Before delving into the details of gilt pricing, data sources and other background information, we first relate the results of this study to the existing literature on pricing anomalies and challenges to the Efficient Markets Hypothesis.

There are several important features to the mispricing of the major gilts documented in this article. They

- lasted for decades

- involved risk-free government bonds

- mispricing was relative, not absolute

- securities were fundamentally perfect substitutes

- securities were widely held, actively traded, and represented huge capital

- there were no short selling constraints

- trading was completely transparent, with prices widely publicized

- trading was on the same exchange

- mispricings were widely recognized as anomalies

- there were many calls for investors to switch to the underpriced securities

What makes the RA underpricing especially remarkable is the structure of the nineteenth-century British financial market, which was very different from that of today. It was dominated by modest accounts, and had low turnover, as is discussed in more detail in Section VI. Most of the institutions that account for the bulk of the assets and the rapid trading today, such as pension funds, private equity, mutual funds and the like, either did not exist at all, or were just starting to appear. The large financial institutions of the day, the insurance companies and the banks, were not very large, compared to the sizes of CA and RA (see Goldsmith I985). Hence decisions were made in a far less centralized fashion than currently, by those controlling the several hundred thousand accounts that existed. Most of those people were 
not very sophisticated financially. On the other hand, the universe of investible securities was small. As late as I 853,70 percent of the capital quoted on the London Stock Exchange was British government debt (Michie I999, p. 89), and almost all of that consisted of just the three major gilts, CA, NR and RA. Trusts were claimed to control a very large fraction of the market, as will be discussed later. For trustees, CA, NR and RA were almost the only tradeable securities they could invest in. So contemporary investors were not leaving decisions of what to buy to a small group of large institutions, and had prices of the handful of relevant securities displayed in almost every newspaper.

According to many press reports, such as the leader from The Times cited at the end of the Introduction, few people understood the differences among the major gilts, and many had only vague ideas about their existence. By itself that is not unusual, and is true today as well, with only a very tiny proportion of the population able to tell the difference between, say, US Treasury bills, notes and bonds, and even fewer able to guess how many dozens of those securities are trading at any given time. Those issues are left to the professionals at large financial institutions. But that was not an option in the nineteenth century, so the lack of solid information about what was basically a total of three relevant major gilts serves as an indication of the low degree of financialization of society in that era.

There is a large literature on mispricings and bubbles. Most papers are devoted either to documenting the existence of an anomaly, and trying to fit it into some model, or else to explaining away the observations as outcomes of rational trading. Some references are Boettke (2010); Camerer (I989); Fleckenstein et al. (20I4); Gilbert (20I I); Lamont and Thaler (2003); Scherbina and Schlusche (2014); Shleifer (2000); Shleifer and Summers (1990); Vayanos and Weill (2008); Xiong (2013); Xiong and Yu (20II). They provide more references and overviews of the literature in this area.

Most of the proposed anomaly mechanisms in the literature clearly do not apply to the gilt mispricings of this article. To take just one example, rational bubbles require high growth rates, which are not relevant to the case of CA and RA, which paid a constant interest rate, and so had limited upside potential. Instead of taking a lot of space explaining why various other concepts are not applicable to gilts, let us consider the few that appear to have some relevance.

Fads and investor sentiments are usually presented in the economics and finance literature as resulting in high turnover, as investors chase after the next Facebook or Google, and trade in and out. In the nineteenth-century gilt market, though, the problem was not excessive trading, but lack of trading. The long-term investors who owned overpriced CA were simply not switching to underpriced RA and NR. Similarly, the concepts of noise traders and herding are most commonly applied to short-term moves in the market (see Chamley 2004). We do see evidence of something like herding among British gilt investors in the nineteenth century, but this mechanism seemed to operate in different ways, far more slowly. Still, the concepts of investor sentiments, noise traders or popularity (Ibbotson and Idzorek 20 I 4; Shleifer 2000) can, in principle, be stretched to cover the proposed explanation of CA 
being the more prestigious and therefore more valuable security. However, those concepts do not have much explanatory power, and it is not clear whether they are any improvement over Charles Mackay's and Gustave Le Bon's crowd psychology ideas of the nineteenth century.

The language of various investment guides from the nineteenth century makes it clear that the writers regarded most of their readers as very unsophisticated, and unlikely to be familiar even with the simple calculations needed to compute accrued interest. However, even the least sophisticated investors should have seen the advantage of exchanging CA for RA once overpricing reached $\mathcal{E}_{\mathrm{I}} \mathrm{\textrm {OOO }}$, as it did for extended periods. At that point, say in February of some year, after CA interest had been paid, the quoted price of a $\mathcal{E}_{\mathrm{IOO}}$ unit of CA that was printed in any newspaper would be at least fo.25 higher than the price of RA. So, the commission and jobber's 'turn' involved in swapping a unit of CA for a unit of RA would be covered by that fo.25, potentially with a bit of cash to pocket if the overpricing exceeded fi.oo. Afterwards, the amount paid out in interest would stay exactly the same, but the next interest payment would come on 5 April, instead of 5 July. Afterwards, all other interest payments would be similarly accelerated by a quarter. The benefits of that should have been clear to anyone, even those not able to do simple interest accrual computations. It is worth noting that such examples show clearly, without doing any computations whatsoever, that factors such as seasonality or term structure of interest rates could not possibly have been responsible for these large mispricings.

The argument of the preceding paragraph shows that there must have been something inhibiting action by long-term investors who were only interested in interest income, such as perpetual trusts. Logically, they should all have moved from CA to RA. Before considering such actors, let us consider some additional factors that differentiated CA from RA.

\section{V}

Many inefficiencies in modern markets are explained as results of a variety of factors, such as limitations on short sales, liquidity and ability to use a security as collateral or to satisfy delivery constraints. To the extent such factors operate, the markets are inefficient, in that prices do not reflect fundamental values, but market participants may all be be behaving rationally, given the constraints that exist.

Some factors, such as liquidity and marginability, were either definitely present and favored CA, or else cannot be shown not to have been present, given the limited data we have about Victorian markets. Hence the argument of this article is based primarily on the existence of large classes of unleveraged investors who were not in position to take advantage of those features of CA. But we first briefly consider the role of such features.

Of the various possible reasons for CA overpricing, liquidity was the one cited most frequently in the nineteenth century. For example, the Economist declared in I86I that 'saleability - ready, easy, satisfactory saleability - is the great quality which a good security should possess', and that '[t]his is the cause of the great partiality in the 
money market for Consols. ... it is half a proverb that "you can sell Consols on a Sunday". 6 There are several counterarguments to such claims. One is that there were extended stretches of time when CA was not overpriced, yet one would think that liquidity would be a factor all the time. Furthermore, it is easy to argue that for most investors, sufficient liquidity was available in RA. The average size of a major gilt account was around $£, 3,000$, as is discussed in Section VI. Jobber quotes had to be honored for $\mathcal{E} \mathrm{I}, \mathrm{OOO}$, and indications are that transactions in the tens of thousands of pounds could be carried out at those quotes. ${ }^{7}$ So the vast majority of accounts could be liquidated entirely without affecting the market price.

Data on jobber quotes, collected in the tables for this project, does show that the bid-ask spread was at double the standard fo.I25 somewhat more frequently for RA (and NR) than for CA. For example, in the $1872-4$ period, the spread on RA was fo.25 in about I 5 percent of the Friday closing quotes, as opposed to no instances for CA. But the prospect of receiving $\mathrm{f}$ O.I25 less on RA than on CA a certain fraction of the time by itself would not justify a premium of $\mathcal{L} \mathrm{I}$.oo, not in a rational world. Still, liquidity is important to investors, even if, as many claim, it is overpriced, just like the equity premium. So we have to allow for liquidity as justifying a higher price of CA for some large classes of investors.

Although that is not documented in the modern literature, the London Stock Exchange was a key part of the British short-term money market (Odlyzko 2016; Parliament I 842). Members of the Stock Exchange were active intermediaries, borrowing and lending, to a large extent based on gilts as collateral. Various large financial actors, such as banks, as well as the Barings and the Rothschilds, probably also used gilts as collateral even without going through the Stock Exchange. We also know that interest rates and margins varied between securities, and between times. But the available information does not allow us to tell whether there was a persistent bias towards one major gilt or another in terms of the interest rates that were charged, say. However, data extracted recently from the gilt ledgers at the Bank of England Archive do not show any extreme reliance on CA as collateral for money market transactions (Odlyzko 20I6). In fact, even the minor gilts administered by the South Sea Company appear to have been used for such purposes with great frequency. Combined with the correlation studies summarized at the end of Section III, this raises questions as to whether the use of gilts in money market transactions could have contributed significantly to the observed CA overpricing. But we simply do not have the necessary information to be sure.

Even if money market features led to CA overpricing, that would not affect the core of the argument of this article, namely that this just created an opportunity for perpetual trusts to gain income by switching out of CA. But there is one other difference we need to consider, which could conceivably have affected the attractiveness of

6 Economist, 2 February I86I, pp. I I4-I5.

7 The Times, 26 April I 860, p. 7, reported a sale of $\mathcal{E}_{\mathrm{I}} \mathrm{oO}, \mathrm{000}$ in nominal value of CA in order to reinvest in the cheaper NR, without any indication that this affected market prices. 
such switches. That is redeemability of gilts. The British government interacted with the gilt market in a variety of ways. When it issued new debt, it did so primarily through the overpriced CA. When it repurchased its debt in the market with budget surpluses, it concentrated its acquisitions on the underpriced RA and NR, with only 23 percent of these transactions in the period I823-90 being in CA (Parliament I89I). Thus in these operations it behaved rationally, and in ways that should have served to reduce CA overpricing.

The British government also carried out a number of redemptions and conversions, when interest rates dropped below the rates at which gilts were issued. In the Goschen operation of I 888-9, it offered holders of CA and RA the same terms, and fo.25 more than to holders of NR, in order to convince the former class to accept the terms right away, and not wait the year they were entitled to. All those investors received about I percent more than the bare minimum they were entitled to, in order to avoid potentially market-disrupting operations. In the Goulburn conversion of $\mathrm{I} 844$ that created NR, investors in all four of the 3.5 percent gilts that were involved were offered identical terms, roughly $2-3$ percent more than the minimum, even though two of those gilts were small enough that they could have been redeemed easily at par. Thus there were no cases of the government treating holders of gilts of similar nature in substantially different ways. Further, there is no evidence that investors were concerned about the possibility of such treatment. In the interests of brevity, we consider just one high-level argument to demonstrate this. It is based on the behavior of market prices. Conversions were likely to occur only when interest rates were low. In early I 845 and in the early i 850 , the non-callability of NR was valued highly, indicating market anticipation of conversion of the 3 percent annuities, which was also reflected in the discussions in the financial press. Yet, as can be seen in Figure I, and in more detail in the tables, those periods were ones of almost perfectly rational relative pricing of CA and RA. The period I $885-7$, preceding the Goschen conversion, also had low interest rates and general expectations of conversion, and it witnessed only a very mild overpricing of CA. More arguments along these lines can be developed. For example, the proposal for a voluntary conversion by Lowe in I 870 led to a decline in gilt mispricing. Once the prospects of that conversion faded, irrationality in prices returned in an even slightly stronger form. The conclusion is that redemption prospects were not responsible for CA overpricing.

\section{I}

Most of the data in this section are drawn from the British government 'Blue Books' . The sizes of CA, RA and NR are given in Table I. In I 860, there were I 3 I,990 CA

8 A small sample of such sources is given in Parliamentary Papers, I86I [2895] LXII.397, p. 200, for the number of accounts in gilts and their distribution; I 870 (52) XLI.2 I 3 for Court of Chancery holdings; I 873 [C.856] [C.856-I] [C.856-II] XxxVII Pt.I.I, XxxviI Pt.II.I, XxxvII Pt.III.I for investments at Cambridge and Oxford; and I884 [C.4073] Xxxix Pt.I.I, I884 [C.4073-i] Xxxix Pt.II.I, I884 
accounts, 35,695 RA accounts and 85,334 NR accounts, so the average account size was about $\mathrm{f}_{3}, \mathrm{OOO}$ in each of these securities. The same 'Blue Book' also provides some statistics about the distribution of account sizes, which were similar for the major gilts, and show that holdings were not dominated by large institutions, with about half the capital in accounts under $\mathcal{E}$ I0,000. ${ }^{9}$ There were only I66 accounts among all three gilts that exceeded $\mathrm{f}_{\mathrm{I}} 33, \mathrm{OoO}$. This is in contrast with modern markets, where large financial institutions are the key players.

By far the largest aggregate holding of gilts was surely trusts. Those were used by Victorians for a variety of purposes, from funding hospitals to holding money for orphans until they came of age. Unfortunately there are no comprehensive statistics on the number of trusts, their investments, or their purposes (Stebbings 2002). One source claimed in I853 that over two-thirds of all property was 'of a fiduciary nature'. ${ }^{10}$ This may have been an overestimate, but probably not a giant one. In I 870, the Court of Chancery held $£ 57.7$ million in gilts (most apparently on behalf of over 20,000 trust accounts that it administered), which must have made it the largest single holder of British national debt at the time, at about 8 percent of the total. ${ }^{11}$ Yet in discussions of trust investments, this court was not cited as an exceptionally large presence in the trust area. Yet another indication is the statement by the management of the South Sea Company in I 847 that much of their equity was held by trusts. ${ }^{12}$ The shares of this company, which were permitted as trust investments, were largely a government annuity, but with a small equity component, so were regarded as much riskier than the gilts themselves. That they should attract trust investments suggests trusts had to be a large market presence.

Much of the trust money was invested literally in perpetuity. An interesting example is that of the Telford Medal, the highest honor bestowed by the Institution of Civil Engineers (ICE) to this day. It was started with the bequest of Thomas Telford. Telford, one of the most eminent civil engineers of his era, left a substantial sum (Telford I838, Appendix X) to be held 'in trust, the interest to be expended in annual premiums under the direction of the Council [of the ICE]'. For the purposes of this study, ICE is valuable, since its members were among the most sophisticated in financial affairs at the time, outside those in the financial industry

[C.4073-II] XXXIX Pt.III.I, I 884 [C.4073-III] XXXIX Pt.IV.i and I 884 [C.4O73-IV] XXXIX Pt.v. I for the London Livery Companies' Commission. More references and more analysis are available in Odlyzko (20I4).

9 This is a rough estimate, since the account statistics that were published only give the number of accounts in certain ranges.

10 Morning Chronicle, 3 June I853, p. 7.

11 It was also among the most irrational. Of the $\mathcal{E} 57.7$ million in gilts, about 75 percent was in CA, apparently the result of some old rule that had only been relaxed in mid-century, which required all long-term investments that were not otherwise restricted to be held in CA. This court was widely regarded as 'dumb money' in financial circles, the source of easy profits for the London Stock Exchange, because of its mode of operations, cf. Economist, 6 February I864, pp. I62-3.

12 The Times, 2 I April I 847, p. 7. 
itself. Civil engineers were mostly employed in small firms, and had to be intimately familiar with the intricacies of cost estimates, cash flows, time value of money and the like. Many ICE members became very wealthy as the result of their investments or running their own businesses, in addition to any professional fees they may have accumulated. Also, the ICE Treasurer was for many years the senior partner of Coutts, the respected private bank, so they did not want for knowledgeable financial advice. Furthermore, annual reports of the ICE were printed in the Minutes of Proceedings of the Institution of Civil Engineers (MPICE). Thus they were visible to all members.

By I880, the ICE had investments amounting to about $£ 50,000$, with about 30 percent of that in trust funds it administered. Relative to the size of the economy, the total of $£ 50,000$ was comparable to perhaps $\mathcal{}$ Ioo million for the UK today, and $\$$ I billion for the US. From I 850 to I 866 , the principal of the Telford Fund, $f^{2,552}$ in CA and $\mathcal{E}^{2,343}$ in RA, was held untouched, and the interest that was not spent was invested mostly in CA ( $\mathcal{I}_{\mathrm{I}}, 776$ vs $\AA_{6} 602$ in $\mathrm{RA}$, according to MPICE, vol. 26, I 866, p. I 3 I), showing substantial irrationality, as CA was overvalued for most of this period. What is perhaps most intriguing is that the accounts from this period show confusion about the names of the gilts. Various designations are used, and in many years the listing of interest ascribes all four of the quarterly interest payments as being derived from a non-existent security, the ' 3 per Cent. Reduced Consols'. Further, the dates those dividends were due, listed as 'Lady-day I 855' and the like, were those that prevailed in the first half of the eighteenth century, before England switched to the Gregorian calendar. These accounts were signed off on by the auditors, selected from among members of the ICE (and thus not professional auditors), two each year, with one new one coming in each year for a twoyear appointment, and were seen by all members of the ICE. Such inattention to an obvious misstatement, year after year, in the presence of scrutiny by the entire membership, and with a changing cast of auditors, is rather strange. But, as will be discussed in Section Ix, it may well reflect the Victorian attitude towards minor financial matters as being beneath the dignity of properly bred gentlemen to bother with.

After the mid I 860s, it appears that the 'unexpended dividends' of the Telford Fund were invested in RA, which shows greater rationality. But later, the I 883 report explained that in the interests of simplification, some reshuffling was carried out, moving some securities between the Telford Fund and the Miller Fund, another trust fund administered by the ICE. This involved some market transactions. The report did not even mention the different market valuations of CA and RA that were involved, nor what happened to the small gain from the exchange. Neither was there any concern that this move was likely illegal, as it led to a gain in the Telford Fund at the expense of the Miller Fund (gains and losses in market values, par values remained the same). This again seems to have reflected an attitude that such things were too small to be bothered with.

The ICE is unusual in that we have a series of printed annual reports. For most charities, what has been found are just a few snapshots in the 'Blue Books'. So they do not provide anywhere near as much information as the ICE reports, or those charities' 
actual accounts, which probably still exist in manuscript form, and with an enormous effort could be examined in detail. Still, those snapshots do document that the Telford Fund was typical. The accounts of the universities of Cambridge and Oxford and of their colleges, or of various London charities, that we find in the 'Blue Books' tend to distinguish between the gilt holdings of those bodies that belonged to them, and trust funds. The former could be liquidated to pay for repairs to their facilities, or new construction, say. Hence liquidity may have mattered for them. The latter, sometimes dating back to the Middle Ages, were of the perpetual investment type, with only income spent, and the direction of investment changing only when absolutely necessary (as when some gilts were converted) or when the trustees decided more lucrative securities could be ventured into. Liquidity should have been irrelevant for such holdings.

We do not have even a rough accounting of how much money was in various kinds of trusts. But from the small sample of trusts for which data was obtained from the 'Blue Books', we can can say with confidence that the perpetual trusts alone must have amounted to many millions of pounds. Those trusts had the clearest incentives to switch from CA to RA. Yet we find practically no traces of such moves, with large amounts invested in CA. Sometimes we find some light traces of rational behavior, as in the case of Greenwich Hospital. When it started to move out of gilts, it sold the overpriced CA first, and RA later.

Even aside from trusts, there were many other investors that also had incentives to move from CA to RA. Many, probably most, individual investors also had long time horizons. The popular attitude seemed to be expressed well by The Times in I 822 in evaluating terminable annuities, ones that paid a fixed sum for a certain number of years, and nothing afterwards. ${ }^{13}$ It claimed they would not be popular, as investors could not easily 'make a provision out of it for posterity'. That was most likely the main reason such annuities were consistently underpriced in nineteenth-century Britain, if we value them with the stadard discounted cash flow method. Studies of the gilt ledgers at the Bank of England Archives shows this attitude is consistent with investor behavior, as we find there a large fraction of accounts with no activity in them, other than collecting interest, for decades (Odlyzko 20I6).

The general conclusion is that there was a very large fraction of gilt holders, who were generally passive, and would have benefited from switching from CA to either RA or NR. They should have traded the liquidity and other features of CA for increased income.

\section{VII}

The project on which this article is based involved a large search of the British literature of the nineteenth century for comments that might explain the observed gilt mispricings. A couple of hundred were found. This section provides a brief summary.

13 The Times, 20 May I822, p. 3. 
It should be emphasized that the overwhelming majority of the citations are from financial journalists, who generally appear to have shared our modern views on economic rationality. In many cases they appear to have accepted the standard explanations for the pricing anomalies (liquidity, use by speculators, etc.), but they still recognized that this represented an opportunity for passive long-term investors to gain by switching from CA to the underpriced RA and NR.

The I 870 Lowe conversion proposal is especially interesting, in that it produced more commentary from other groups in society. The long leader in The Times on this topic is very enlightening, as it shows how little was thought by the staff of this paper to be known on this topic even among its readers, who included much of the upper classes. ${ }^{14}$ Overall, gilt mispricing never became a big issue for the press, and never attracted much attention other than from financial journalists. That is probably part of the reason it persisted for as long as it did.

In the early part of the nineteenth century (before I 830 , say), most references described rational pricing as something to be expected, and as something that markets seldom deviated from. However, a couple of references mentioned gilt mispricing as frequent, possibly based on memory of earlier times. (This study is based on data from I 823 and later. Some non-systematic collections of prices from earlier periods, before I 8 I 5 , do indicate that mispricings were common then.) The first substantial overpricing of CA observed in this study, in the early i 830 s, led to several news citations, all of which described it as abnormal, and bound to be eliminated soon, as it was, although only for a while. Later, as the mildly and intermittently irrational pricing continued for much of the I830s and early I840s, we find some more citations. They include an amusing demonstration of short memories among journalists and of the tendency of people to invent rationalizations for whatever happens in the market. In July I 839, after about a year of rational CA vs RA pricing, CA overpricing reappeared. The Spectator was surprised by the anomaly, as it regarded rational pricing as the norm. But the anomaly persisted. When it vanished in October I 842, this paper was surprised again, as it had gotten used to the irrationality. It argued that since "all the speculative operations" were confined to CA, CA overpricing was normal. Then, when CA became overpriced yet again during the Railway Mania, the Spectator was surprised once more in April I 846, as it had again gotten used to rational pricing, and expected the anomaly to be quickly eliminated by arbitrage. ${ }^{15}$

The Railway Mania, usually dated to I 844 through I 849, was associated with substantial gilt mispricing, which led to considerable press coverage. (To some extent gilts were pushed to the background by the preoccupation with the more speculative railway investments, but this was more than counterbalanced by the large expansion of coverage of financial markets, and greater sophistication in financial analysis.) There were some notable press campaigns, including multi-year ones by the Illustrated

14 The Times, Is February i870, p. 7.

15 Financial ('money market') column, Spectator, 27 July I839, p. 702; 22 October I 842, p. IOI 7; I I April I 846, p. 346. 
London News and Freeman's Journal, to persuade their readers to take advantage of the seemingly enticing arbitrage opportunities. Another long campaign against gilt mispricing was waged by the Economist from late i 859 to late I86I.

By the late I860s, it appears that there were fewer mentions of gilt pricing anomalies. To some extent this may have been due to gilts becoming less important, as the financial markets developed. But it may also reflect resignation, as the mispricing continued. One item, published in I874, cited the mispricing and noted that it was 'a standing Stock Exchange anomaly', but that it could not 'be too often pointed out to intending investors ..., or to those who hold [CA] and who wish to continue to hold [gilts]' as it was to their advantage to switch to RA and NR. ${ }^{16}$ But this was not pointed out too often. Financial editors may have decided that there was no point in annoying their readers by citing facts that were obvious to some, and were being ignored by others. Possibly in a similar vein, modern newspapers don't devote much space to the harms of smoking.

\section{VIII}

Nineteenth-century British gilt pricing anomalies are interesting for a variety of reasons, not least because they demonstrate a wide variety of views on the relative valuations of the major gilts, something that there should not have been any question about. The market produced an equilibrium that diverged from the unambiguously correct value. But we can discern some groups that appear to have had views different from the market consensus, and from the correct views. Unfortunately no opinions have been found so far of the people who held these views, so we do not know what motivated them.

In I880, Parliament passed a law allowing customers of the Post Office Savings Bank to invest directly in gilts. From the start of operations of this new service on 22 November I880 through 3I March I88I, customers made the investments shown in Table 2. Data are from the annual report of the Postmaster General. ${ }^{17}$

As noted in Section VI, the average size of an account in the major gilts was around f3,ooo. The accounts represented in Table 2 on average were less than 2 percent of that. So they represented holdings of much poorer strata of the population. It is noteworthy that while the volume of CA was about twice that of NR, these investors put about as much money into the underpriced NR as into the overpriced CA. So in that sense they do show some rationality. But why the preference for NR over RA? It is unreasonable to expect anyone at that time to have been able to predict that Goschen

16 Financier, 2 June I874, p. 3, reprinted in an abbreviated form in Leeds Mercury, 2 June I874, p. 4.

17 Parliamentary Papers i 88 I [C.3006] xxix.583, p. 27. There were also some liquidations, which are not shown in this table. The next few reports in this series do give the total amount invested by customers in gilts, but without providing separate figures for CA, RA and NR, so they provide no useful information for us. However, a later report provides circumstantial evidence that the balance of investments did not change until the Goschen conversion. 
Table 2. Post Office Savings Bank customer investments

\begin{tabular}{lccc}
\hline \hline Gilt & Number of investments & Aggregate investments $(\mathcal{E})$ & Average investment $(\mathcal{E})$ \\
\hline CA & 3,202 & I 73, I33 & 54.07 \\
RA & $48 \mathrm{I}$ & $26,30 \mathrm{I}$ & 54.68 \\
NR & $3,29 \mathrm{I}$ & $\mathrm{I} 87,309$ & 56.92 \\
\hline \hline
\end{tabular}

Note: Investments in gilts, 22 November I880 - 3 I March I88I. Data from Parliamentary Papers.

in I 888 would offer holders of RA more than the holders of NR (even if only fo.25 more), but there did not seem to be any reason to regard RA as less desirable than NR. Market transactions and jobber quotes around I 880 were essentially identical for the two. So it seems that there was some popular prejudice against RA that we have not found any documentation on in the literature.

A group of even poorer investors showed even greater rationality. Friendly Societies, essentially mutual-help groups of the poor, had (in a small, but hopefully unbiased sample $\left.{ }^{18}\right) 9$ accounts containing a total of $\mathcal{E} 3,592$ of CA and I5 accounts with $\mathcal{E}_{\mathrm{I}} 3,883$ of NR, and none with RA. So here we again find the same puzzling bias against RA as among Post Office Savings Bank investors, but a greater bias towards the underpriced NR.

\section{IX}

One voice that is almost completely missing from the opinions about gilt mispricing that have been found is that of economists. Aside from Giffen, none appear to have written about this phenomenon, even though it overlapped the careers of John Stuart Mill, Alfred Marshall and many other significant thinkers. Were they oblivious to what was happening in the gilt markets, or did they suppress any mention of the anomalies as an inconvenient fact that clashed with their theories? Those might seem the obvious choices. However, a study of nineteenth-century thought shows that the British elite regarded investors as frequently irrational, and markets as often inefficient. It is more likely that the political economists of that era shared this view, and so regarded gilt mispricing as just one of many market imperfections, not worthy of special notice. But this is a supposition, and it would be valuable to find some solid information.

A large contribution to the gilt mispring probably came from cultural factors. The early Victorian society was in transition, and many attitudes, such as disdain for finance, may have had an effect on what they discussed and did. Section vi outlined

18 Reports on Friendly Societies, Parliamentary Papers I882 (373) (373-I) (373-II) LXVI. I, 97, I77, p. 24, and later ones. 
the investment behavior of the ICE that seems economically irrational to us, but did not appear to cause any controversy. Similar behavior can be observed with other institutions. As an example, the law for sales of life annuities by the government specified that the average of the prices of CA and RA (after stripping out the accrued interest) should be used in the price formula. This may reflect awareness that sometimes there was a pricing anomaly. On the other hand, sometimes Acts were passed by Parliament that ignored such differences. For example, in I8I5, the South Sea Company (SSC) gave up its trade monopoly. In return it received a dividend subsidy until a 'Guarantee Fund' accumulated to a nominal value of f6ro,464, which was then to be turned over the SSC. The relevant Act (55 Geo. 3 c. 57) only specified that the Guarantee Fund was to be composed of 3 percent annuities. When the SSC received this Fund in early I845, it consisted of $\mathcal{E} 483,382$ of RA and $\mathcal{E}_{\mathrm{I} 27,083} \mathrm{CA}$. While the fund was accumulating, the SSC was aware of its composition. But in none of the SSC corporate papers has any discussion been found of the mix of gilts in this Fund. However, once the Guarantee Fund was turned over to the SSC, this company became involved in disputes with the government about some small financial details, such as ownership of accrued interest. During this dispute, the dredged up the fact that 80 percent of the Guarantee Fund was in RA, and since RA was underpriced by f $^{0.25}$ relative to CA, they claimed were owed an additional f, $\mathrm{I}, 209$. The government rejected this claim, arguing that they had fulfilled not just the letter, but also the 'spirit \& intention' of the I8 I5 Act. ${ }^{19}$ There are several intriguing features to this story. One is that no notice was taken publicly of CA overpricing in the I 8 I 5 Act, nor during the subsequent three decades. Another is that most of the securities purchased for the Fund were in RA, which was generally underpriced during this period. (The 20 percent in CA may have been purchased during the extended period in the I 820 s when CA and RA were priced rationally.) This may mean that lower-level officials in the government did what economic logic suggests, and what may have been below the dignity of Parliament and their superiors to notice, and executed the purchase in the less expensive RA. Yet another curiosity is that there was yet another security that could have been purchased for the Guarantee Fund, the Bank Annuity of I 726. It also paid 3 percent, but had small capital, and when it traded, it usually fetched 2-3 percent less than CA (with which it shared interest payment days). Why didn't the government purchase this security instead of at least part of the CA and RA that was bought? That is a mystery. So is the fact that in response to the SSC claim in 1845 , the government (in the person of the famous Charles Edward Trevelyan) did not point out that it could have fulfilled the letter of the I 8 I 5 Act by giving the SSC securities worth far less than RA.

The general conclusion is that there were various cultural and social features of Victorian society that very likely contributed to the observed mispricing. Basic economic incentives did operate, but may have been attenuated by special factors of that time. Some better-known factors, such as the agency problem, in which trust

19 SSC Court of Directors minutes, 5 June and 2 July I 845 , British Library, Add. MS 2554 I. 
administrators did not have a strong incentive to maximize returns, almost surely contributed as well.

The factors cited above, while plausible, still do not provide an explanation for why CA would become overpriced in the first place. Even in the absence of the "passive arbitrage' of selling CA to purchase RA, there was a constant flow of market transactions. The sales should have been concentrated in the overpriced CA and purchases in the underpriced RA, and that alone should have eliminated the anomaly. That this did not happen suggests that there was some preference for CA that we do not fully understand.

Giffen in I 877 clearly thought that CA overpricing was irrational (Giffen I879, p. 95). He described it in a section on market anomalies, following a passage in which he ascribed what he thought was the excessive price of Bank of England shares to the prestige that ownership of them brought. He was explicit in saying he had asked around. (Until shortly before writing that passage, he had been in a perfect position to inquire, as the financial editor of the Economist.) Several other observers have been found in the nineteenth century who explicitly attributed gilt mispricing to investor irrationality. The most thoughtful of these was the writer of a piece in the Leeds Mercury in I876, who concluded that a likely contributor to CA overpricing was the irrational prestige attached to the term 'Consols'. ${ }^{20}$ The term was used with increasing frequency, even when any of the major gilts was meant. However, that does not explain what appeared to be frequent CA overpricing episodes before I 823. Nor does it explain the occasional RA overpricing, such as that of mid 1787 that is documented in the tables. It also does not explain the frequent mispricing of the minor gilts. Thus we are left with the prospect that gilt prices were influenced to a substantial extent by various rumors and opinions, diffusing in the strange ways that modern research on social networks, communication dynamics, information diffusion, etc., is beginning to elucidate.

\section{$\mathrm{X}$}

Far more work is called for on nineteenth-century gilt pricing. The research documented here has just scratched the surface. Complete price records of gilts (and other securities, for comparative purposes) are needed, both realized prices and quotes, to map the patterns of mispricing. Far more intensive searches should be made of various contemporary sources, printed or not, to find out what various people thought about this phenomenon.

But we can already draw some conclusions, beyond adding to the literature what seem to be the most striking counterexamples known to the Efficient Markets Hypothesis and the Law of One Price. Starting from the most concrete, to the five pitfalls identified by Klovland in his work on the estimation of the yield on CA (Klovland 1994), we can add a sixth, namely that CA is not sufficient to give a

20 Leeds Mercury, 26 July I 876, p. 4. 
complete picture of risk-free long-term interest rates. Other gilts (primarily RA) are in principle just as valid, and produce different answers. The effect is not very large, just a couple of basis points, but it is comparable to some of the adjustments that have been made by Klovland and other investigators in earlier studies.

Next, various studies that assume market rationality in pricing of government bonds (such as Alquist 20I0; Klovland I994, to cite just two that rely on data about gilts in the nineteenth century) should be reconsidered. The irrational relative pricing of CA and RA means that we cannot assume the existence of a welldefined term structure of interest rates, for example. More generally, the presence of long-term pricing anomalies among the most important financial instruments of the nineteenth century adds weight to the findings of modern behavioral finance in suggesting there is far less rationality in the markets than is often assumed. It is easy to dismiss CA overpricing in the $\mathrm{I}_{3} \mathrm{I}-87$ period as irrelevant, due to the lack of sophistication of investors during the early formative period of corporate capitalism. But that attitude is questionable. Sophistication is a relative term. It is not clear that modern investors, faced with far more complicated choices (often deliberately obfuscated) than those faced by gilt investors in the nineteenth century, are making better decisions. Much of what is explained away as a result of rational investors operating on imperfect information may well be the result of the whims of crowd psychology.

Submitted: 5 March 2015

Revised version submitted: 26 July 2016

Accepted: 3 August 2016

First published online: 9 January 2017

\section{References}

ALQUIST, R. (20 Iо). How important is liquidity risk for sovereign bond risk premia? Evidence from the London Stock Exchange. Journal of International Economics, 82, pp. 219-29.

ATACK, J. and NEAL, L. (2009). The Origins and Development of Financial Markets and Institutions: From the Seventeenth Century to the Present. Cambridge: Cambridge University Press.

BOETTKE, P. J. (20 I0). What happened to 'efficient markets'? The Independent Review, I4, pp. 363-75.

BROWN, R. L. and EASTON, S. A. (1989). Weak-form efficiency in the nineteenth century: a study of daily prices in the London market for 3 percent consols, I82I-I860. Economica, 56, pp. 6I-70.

BROWN, W. O., BURDEKIN, R. C. K., and WEIDENMIER, M. D. (2006). Volatility in an era of reduced uncertainty: lessons from Pax Britannica. Journal of Financial Economics, 79, pp. 693-707.

CAMERER, C. F. (I989). Bubbles and fads in asset markets: a review of theory and evidence. Journal of Economic Surveys, 3, pp. 3-38.

CAPIE, F. and WEBBER, A. (1985). A Monetary History of the United Kingdom, 1870-1982, vol. I: Data, Sources, Methods. London: George Allen \& Unwin.

CHAMLEY, C. (2004). Rational Herds: Economic Models of Social Learning. Cambridge: Cambridge University Press.

DAVIS, L. and NEAL, L. (I998). Micro rules and macro outcomes: the impact of microstructure on the efficiency of security exchanges: London, New York, and Paris, I800-I9I4. American Economic Review, 88, pp. 40-5.

FLECKENSTEIN, M., LONGSTAFF, F. A. and LUSTIG, H. (20I4). Why does Treasury issue TIPS? The TIPS-Treasury bond puzzle. Journal of Finance, 69, pp. 2 I 5 I-97. 
GAYER, A. D., ROSTOW, W. W. and SCHWARTZ, A. J. (I953). The Growth and Fluctuations of the British Economy, 1790-1850: An Historical, Statistical, and Theoretical Study of Britain's Economic Development. Oxford: Oxford University Press.

GIFFEN, R. (I879). Stock Exchange Securities: An Essay on the General Cause of Fluctuations in their Price. 2nd edn. London: George Bell and Sons.

GILBERT, C. L. (2O I I). Anomalies in economics and finance. Manuscript available at http://ssrn.com/ abstract $=1757735$

GOLDSMith, R. W. (I985). Comparative National Balance Sheets: A Study of Twenty Countries, 1688-1978. Chicago: University of Chicago Press.

GREEN, D. R., OWENS, A., MALTBY, J. and RUTTERFORD, J. (20 I I). Men, Women, and Money: Perspectives on Gender, Wealth, and Investment, 1850-1930. Oxford: Oxford University Press.

HEIM, C. E. and MIROWSKI, P. (I987). Interest rates and crowding-out during Britain's industrial revolution. Journal of Economic History, 47, pp. I I 7-39.

HOMER, S. and SYLLA, R. (I996). A History of Interest Rates. 3rd edn. New Brunswick, NJ: Rutgers University Press.

IBBOTSON, R. G. and IDZOREK, T. M. (20I4). Dimensions of popularity. Journal of Portfolio Management, 40, pp. 68-74.

KLOVLAND, J. T. (I994). Pitfalls in the estimation of the yield on British Consols, I 850-I9I 4. Journal of Economic History, 54, pp. I64-87.

KUIPERS, D. R. (2008). Does deliverability enhance the value of US Treasury bonds? Journal of Futures Markets, 28, pp. 264-74.

KYNASTON, D. (I994). The City of London, vol. I: A World of Its Own, 1815-189o. London: Chatto \& Windus.

LAGOS, R. and ROCHETEAU, G. (2009). Liquidity in asset markets with search frictions. Econometrica, 77, pp. 403-26.

LAMONT, O. A. and THALER, R. H. (2003). Anomalies: the Law of One Price in financial markets. Journal of Economic Perspectives, I7, pp. I9I-202.

LEVI, L. (I 862). On the progress and economical bearings of national debts in this and other countries. Journal of Statistical Society of London, 25, pp. 3 I 3-38.

MICHIE, R. C. (I999). The London Stock Exchange: A History. Oxford: Oxford University Press.

MITCHELL, B. R. (I988). British Historical Statistics. Cambridge: Cambridge University Press.

MITCHELL, H., BROWN, R. and EASTON, S. (2002). Old volatility - ARCH effects in I9th century consol data. Applied Financial Economics, I2, pp. $30 \mathrm{I}-7$.

MORGAN, E. V. and THOMAS, W. A. (I96I). The Stock Exchange: Its History and Functions. London: Elek Books.

MUSTO, D., NINI, G. and SCHWARZ, K. (20I5). Notes on bonds: liquidity at all costs in the Great Recession. Manuscript available at http://ssrn.com/abstract $=2625 \mathrm{IO} 7$

NASH, R. L. (I874). Fenn's Compendium of the English and Foreign Funds, ... I2th edn. London: Effingham Wilson.

NEAL, L. (1993). The Rise of Financial Capitalism: International Capital Markets in the Age of Reason. Cambridge: Cambridge University Press.

NEAL, L. and DAVIS, L. (2006). The evolution of the structure and performance of the London Stock Exchange in the first global financial market, I8I2-I9I4. European Review of Economic History, Io, pp. 279-300.

ODLYZKO, A. M. (2OI4). Supplementary material for 'Economically irrational pricing of I9th century British government bonds'. Manuscript available at http://ssrn.com/abstract $=2435437$

ODLYZKO, A. M. (20I6). Financialization of the early Victorian economy and the London Stock Exchange. Manuscript available at http://ssrn.com/abstract=2787154

PARLIAMENT (I 842). Exchequer Bills Forgery. Report of the Commissioners. Parliamentary Papers I 842 [409] Xviii.I39.

PARLIAMENT (I 857). Report from the Select Committee on Bank Acts. Parliamentary Papers I 857 Session 2 (220) (220-I) x Pt.i.I, x Pt.ii.I.

PARLIAMENT (I89i). National Debt. Report by the Secretary and Comptroller General of the Proceedings of the Commissioners for the Reduction of the National Debt, from I786 to 3 IMarch I 890. Parliamentary Papers i 890-I [6539] xlviii.5 I I. 
REINHART, C. M. and ROGOFF, K. S. (2009). This Time Is Different: Eight Centuries of Financial Folly. Princeton: Princeton University Press.

SCHERBINA, A. and SCHLUSCHE, B. (20I4). Asset price bubbles: a survey. Quantitative Finance, I4, pp. 589-604.

SHLEIFER, A. (2000). Inefficient Markets: An Introduction to Behavioral Finance. Oxford: Oxford University Press.

SHLEIFER, A. and SUMMERS, L. (I990). The noise trader approach to finance. Journal of Economic Perspectives, 4, pp. 19-33.

SIEGEL, J. J. (I992). The real rate of interest from I 800-I990: a study of the US and the UK. Journal of Monetary Economics, 29, pp. 227-52.

STEBBINGS, C. (2002). The Private Trustee in Victorian England. Cambridge: Cambridge University Press.

TELFORD, T. (I838). Life of Thomas Telford, Civil Engineer, Written by Himself, ..., ed. J. Rickman. London: James and Luke G. Hansard and Sons.

TUCK, H. (I 845). The Railway Shareholder's Manual; Or, Practical Guide to the Railways of Great Britain, ... 3 rd edn. London: Effingham Wilson.

VAYANOS, D. and WEILL, P. (2008). A search-based theory of the on-the-run phenomenon. Journal of Finance, 63, pp. I $36 \mathrm{I}-99$.

WADE, R. W. (I806). The Stock-holder's Assistant. Containing a Table Shewing the Proportional Prices Which the Different Funds Should Bear to Each Other, and ... London: H. D. Steel.

XIONG, W. (2OI3). Bubbles, crises, and heterogeneous beliefs. Manuscript available at www.princeton. edu/ $\sim$ wxiong/papers/review.pdf

XIONG, W. and YU, J. (20II). The Chinese warrants bubble. American Economic Review, IoI, pp. $2723-53$. 